\title{
Organocatalytic asymmetric Michael addition of unprotected 3-substituted oxindoles to 1,4-naphthoquinone
}

\author{
Jin-Sheng Yu, Feng Zhou, Yun-Lin Liu and Jian Zhou*
}

\section{Letter}

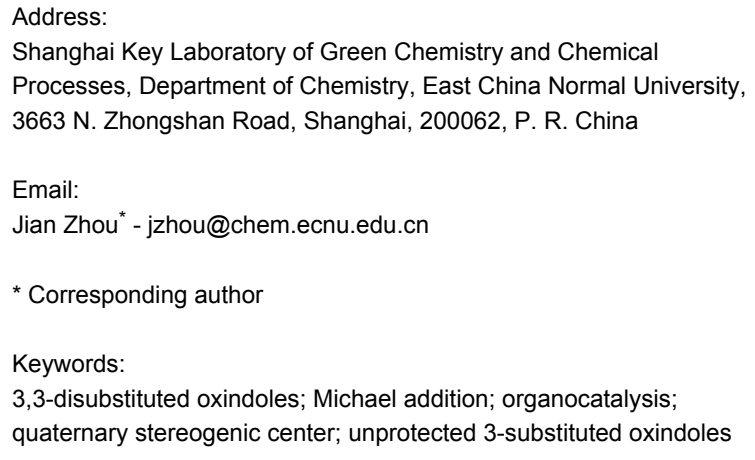

\begin{abstract}
We reported the first example of organocatalytic Michael addition of unprotected 3-prochiral oxindoles 1 to 1,4-naphthoquinone. Quinidine derivative (DHQD) ${ }_{2} \mathrm{PYR}$ was found to be able to catalyze this reaction in up to $83 \%$ ee, with moderate to excellent yields. This method could be used for the synthesis of enantioenriched 3,3-diaryloxindoles, and the catalytic synthesis of which was unprecedented.
\end{abstract}

\section{Introduction}

The catalytic asymmetric synthesis of 3,3-disubstituted oxindoles has recently received great attention because of the wide occurrence of this structural motif in natural products and pharmaceutically active compounds [1-3]. In addition, structure-activity relationship studies have revealed that the absolute configuration and the substituent of the $\mathrm{C} 3$ position of oxindole greatly influenced the biological activities [4]. Accordingly, the development of efficient synthetic methods to enable the synthesis of 3,3-disubstituted oxindoles in great structural diversity is of current interest, and much progress had been made in the catalytic enantioselective synthesis of 3-hydroxyoxindoles [5-10], 3-aminooxindoles [11-15] and 3-quaternary oxindoles [16-20]. Despite achievements, the catalytic asymmetric syn- thesis of 3,3-diaryloxindoles has not been reported. This is possibly due to the challenge in the construction of such congested quaternary stereogenic centers. Only Sammakia tried the $S_{N} A r$ reaction of unprotected 3-phenyloxindole with chiral electron-deficient 5-halooxazoles, promoted by 1.0 equiv of $\mathrm{Cs}_{2} \mathrm{CO}_{3}$ [21], with ca. 1:1 diastereoselectivity obtained.

In this context, we are interested in the catalytic economical asymmetric diverse synthesis of 3,3-disubstituted oxindoles, using cheap and easily available starting materials and simple chiral catalysts to facilitate biological evaluation. We have developed the catalytic asymmetric addition of acrolein, allyltrimethylsilane or difluoroenoxysilanes to isatins to furnish 
differently substituted enantioenriched 3-hydroxyoxindoles [2224]. For the synthesis of chiral 3-aminooxindoles, we developed the first example of catalytic asymmetric addition of nucleophiles to isatin-derived ketoimines using TMSCN [25] and the amination of unprotected 3-prochiral oxindoles using di-tert-butyl azodicarboxylate $[26,27]$. To construct the $\mathrm{C} 3$ quaternary stereogenic carbon center, we have designed a novel cinchona alkaloid-based phosphoramide bifunctional catalyst to realize a highly enantioselective Michael addition of both unprotected 3-alkyl- and 3-aryloxindoles to nitroolefins [28]. Based on these results, together with our efforts in the synthesis of unsymmetric 3,3-diaryloxindoles [29], we try to develop a catalytic asymmetric method to enantioenriched 3,3-diaryloxindoles.

In 2007, Jørgensen and coworkers pioneered the organocatalytic asymmetric addition reactions to quinones [30,31] which turned out to be a powerful strategy for the $\alpha$-arylation of $\beta$-ketoesters and aldehydes. Inspired by their work, we anticipated that the catalytic asymmetric addition of 3-aryloxindoles to quinones would possibly install a hydroquinone moiety at the C3 position of oxindole to furnish the desired chiral 3,3-diaryloxindoles. It also came to our attention that, while the addition of 3-prochiral oxindole to a variety of Michael acceptors had been studied [32-46], the use of quinones as the Michael acceptor had not been realized. Therefore, in this letter we are going to report our initial results about the catalytic asymmetric Michael addition of unprotected 3-prochiral oxindoles to 1,4naphthoquinone.

\section{Results and Discussion}

We began the reaction development by the evaluation of different chiral catalysts derived from cinchona alkaloids in the reaction of 3-phenyloxindole 1a and 1,4-naphthoquinone (2a), with ethyl acetate (EtOAc) as the solvent at $0{ }^{\circ} \mathrm{C}$ (Table 1 , Figure 1). A variety of bifunctional cinchona alkaloid-derived

Table 1: Condition optimization for the reaction of $\mathbf{1 a}$ and $\mathbf{2 a}$.<smiles>O=C1Nc2ccc(Br)cc2C1c1ccccc1</smiles>

1 a $(1.0$ equiv $)$<smiles>c1ccc(-c2ccccc2)cc1</smiles><smiles>O=C1C=CC(=O)c2ccccc21</smiles>

2a ( 1.5 equiv) cat. $(10 \mathrm{~mol} \%)$

solvent $(0.05 \mathrm{M})$

$0{ }^{\circ} \mathrm{C}, 5 \mathrm{~d}$

\begin{tabular}{|c|c|c|c|c|c|}
\hline Entry ${ }^{a}$ & Cat. & Solvent & Additive & Yield of $\mathbf{3 a}(\%)^{b}$ & ee $(\%)^{c}$ \\
\hline 1 & 5 & EtOAc & - & 52 & $43^{d}$ \\
\hline 2 & 6 & EtOAc & - & 61 & 59 \\
\hline 3 & 7 & EtOAc & - & 40 & 14 \\
\hline 4 & 8 & EtOAc & - & 34 & 4 \\
\hline 5 & 9 & EtOAc & - & 14 & 15 \\
\hline 6 & 10 & EtOAc & - & 60 & $64^{d}$ \\
\hline 7 & 11 & EtOAc & - & 64 & $73^{d}$ \\
\hline 8 & 12 & EtOAc & - & 51 & 77 \\
\hline 9 & 12 & THF & - & 50 & 64 \\
\hline 10 & 12 & Acetone & - & 61 & 64 \\
\hline 11 & 12 & $\mathrm{CH}_{3} \mathrm{CN}$ & - & 32 & 47 \\
\hline 12 & 12 & $\mathrm{DCM}$ & - & 21 & 36 \\
\hline 13 & 12 & Toluene & - & 31 & 73 \\
\hline 14 & 12 & EtOAc & MS $4 \AA$ & 43 & 80 \\
\hline 15 & 12 & EtOAc & MS $5 \AA$ & 29 & 70 \\
\hline 16 & 12 & EtOAc & $\mathrm{H}_{2} \mathrm{O}$ (5.0 equiv) & 50 & 78 \\
\hline 17 & 12 & EtOAc & $\mathrm{H}_{2} \mathrm{O}$ (10.0 equiv) & 50 & 78 \\
\hline 18 & 12 & EtOAc & $\mathrm{PhCO}_{2} \mathrm{H}^{\mathrm{e}}$ & 33 & 76 \\
\hline 19 & 12 & EtOAc & $(S)-\mathrm{BINOL}^{\mathrm{e}}$ & 36 & 40 \\
\hline 20 & 12 & EtOAc & $(R)-\mathrm{BINOL}^{\mathrm{e}}$ & 43 & 77 \\
\hline 21 & 12 & EtOAc & $\mathrm{LiCl}^{\mathrm{e}}$ & 65 & 4 \\
\hline
\end{tabular}

${ }^{a}$ Reactions were run on a $0.10 \mathrm{mmol}$ scale. ${ }^{b}$ Isolated yield. ${ }^{c}$ Determined by chiral HPLC analysis. ${ }^{\mathrm{d}}$ Opposite enantiomer. ${ }^{\mathrm{e}} 10 \mathrm{~mol} \%$ used. 
<smiles>C=CC1CC2CCN1C2C(O)c1ccnc2ccc(OC)cc12</smiles>

5<smiles>C=CC1CC2CCN1C2C(O)c1ccnc2ccc(OC)cc12</smiles>

6<smiles>C=CC1CC2CCN1CC2C(NP(=O)(c1ccccc1)c1ccccc1)c1ccnc2ccc(OC)cc12</smiles>

7<smiles>C=CC1CC2CCN1C2C(NC(=S)Nc1cc(C(F)(F)F)cc(C(F)(F)F)c1)c1ccnc2ccc(OC)cc12</smiles><smiles>C=CC1CC2CCN1C2C(NS(=O)(=O)c1ccc(OC)cc1)c1ccnc2ccc(OC)cc12</smiles>

9<smiles>C=CC1C2CCC1N2CC(Oc1nc(-c2ccccc2)cc2cc(OC)ccc12)c1nc(-c2ccccc2)c2cc(OC)ccc2n1</smiles>

$11(\mathrm{QN})_{2} \mathrm{PYR}$

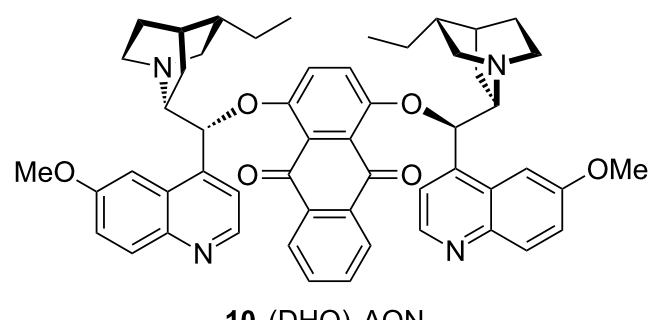

$10(\mathrm{DHQ})_{2} \mathrm{AQN}$<smiles>CCCC1C2CCN(C2CC)C1c1cc(OC(c2ccnc3ccc(OC)cc23)c2ccnc3ccc(OC)cc23)nc(-c2ccccc2)c1-c1ccccc1</smiles>

Figure 1: Cinchona alkaloid-derived catalysts screened for condition optimization (Table 1).

catalysts 5-9 were first tried, aiming to facilitate the reaction by the dual activation of both reaction partners, with H-bonding donor moiety of the catalyst to activate quinone $\mathbf{2} \mathbf{a}$ and the tertiary amine to deprotonatively activate oxindole $\mathbf{1}$. The reaction generally proceeded slowly, and only the oxidation product, 1,4-naphthoquinone derivative 3a, was obtained in moderate yield after five days. No hydroquinone product $\mathbf{4}$ was detected by TLC and NMR analysis of the crude reaction mixture. While the simple quinine and quinidine as catalysts could deliver product 3a in 59\% ee (Table 1, entry 2), all other bifunctional catalysts turned out to be much less enantioselective (Table 1, entries 3-5). However, the dinuclear Brønsted base catalysts 10-12 could achieve higher ee for the desired product 3a with comparable yields (Table 1, entries 6-8). When the hydrogenated catalyst $\mathbf{1 2}$ was used, 77\% ee for product 3a was obtained with $51 \%$ yield (Table 1, entry 8 ). In light of this, we used catalyst $\mathbf{1 2}$ for the following screenings.

We further examined the solvent effects, and found that EtOAc turned out to be the most suitable solvent which afforded product 3a in highest ee (Table 1, entries 8-13). Since the reactivity was unsatisfactory, we further tried the use of some additives to improve the reaction rate. The use of MS $4 \AA$ could improve the enantioselectivity to $80 \%$, but decreased the yield from $51 \%$ to
$43 \%$ (Table 1 , entry 8 versus 14 ). The use of MS $5 \AA$ had a negative effect on both the reactivity and the enantioselectivity (Table 1, entry 15). Water had no obvious effect on the reaction outcome (Table 1, entries 16 and 17). The addition of acids led to diminished yield and enantioselectivity (Table 1, entries 18-20).

Based on these screenings, we determined to examine the substrate scope by running the reaction at $0{ }^{\circ} \mathrm{C}$ in EtOAc, with $20 \mathrm{~mol} \%$ of (DHQD) ${ }_{2}$ PYR 12 to improve the reactivity. Different substituted 3-prochiral oxindoles were first examined and the results are shown in Table 2. An electron-withdrawing substituent at the $\mathrm{C} 5$ position of the oxindole had a positive effect on the reactivity and enantioselectivity of the reaction. The corresponding products $\mathbf{3 a}-\mathbf{d}$ could be obtained in good to excellent yields with up to $81 \%$ ee. Without an electron-withdrawing group, products $\mathbf{3 e}$ and $\mathbf{3 f}$ were obtained in diminished yields and enantioselectivities. Different aryl substituents at the C3 position were also investigated, the corresponding products $3 \mathbf{g}-\mathbf{k}$ were obtained in acceptable yields and up to $83 \%$ ee. We also tried if this method could be extended to 3-alkyloxindoles but had to find out that product $\mathbf{3 1}$ was obtained in only moderate enantioselectivity and yield. The absolute configuration of product $\mathbf{3 f}$ was determined to be $(S)$ by chemical trans- 
Table 2: Substrate scope of unprotected 3-prochiral oxindoles ${ }^{a-c}$.<smiles>[R]c1cccc2c1C([R])C(=O)N2</smiles>

1 (1.0 equiv)<smiles>O=C1C=CC(=O)c2ccccc21</smiles>

2 (1.5 equiv)<smiles></smiles>

EtOAc, $0^{\circ} \mathrm{C}$<smiles>[R]c1ccc2c(c1)C1([R])C(=O)C(=CC2=O)C(=O)Nc2ccccc21</smiles>

Product, yield, enantioselectivity and reaction time<smiles>O=C1C=C([C@]2(c3ccccc3)C(=O)Nc3ccc(Br)cc32)C(=O)c2ccccc21</smiles>

3a

$70 \%$ yield, $79 \%$ ee, $5 d$<smiles>Cc1ccc2c(c1)[C@@](C1=CC(=O)c3ccccc3C1=O)(c1ccccc1)C(=O)N2</smiles>

$46 \%$ yield, $69 \%$ ee, 9 d<smiles>Cc1cccc([C@]2(C3=CC(=O)c4ccccc4C3=O)C(=O)Nc3ccccc32)c1</smiles>

$3 \mathbf{i}$<smiles>O=C1C=C([C@]2(c3ccccc3)C(=O)Nc3c(Br)cc(Br)cc32)C(=O)c2ccccc21</smiles>

3b

$97 \%$ yield, $80 \%$ ee, $6 \mathrm{~d}$<smiles>O=C1C=C([C@]2(c3ccccc3)C(=O)Nc3ccccc32)C(=O)c2ccccc21</smiles>

$51 \%$ yield, $70 \%$ ee, $9 \mathrm{~d}$<smiles>O=C1C=C([C@]2(c3ccc4ccccc4c3)C(=O)Nc3ccc(Br)cc32)C(=O)c2ccccc21</smiles>

3j<smiles>O=C1C=C([C@]2(c3ccccc3)C(=O)Nc3ccc(Cl)cc32)C(=O)c2ccccc21</smiles>

$74 \%$ yield, $81 \%$ ee, 6 d<smiles>O=C1C=C([C@]2(c3cccc(Cl)c3)C(=O)Nc3ccccc32)C(=O)c2ccccc21</smiles>

3g

$76 \%$ yield, $81 \%$ ee, $6 \mathrm{~d}$<smiles>O=C1C=C([C@]2(c3cccs3)C(=O)Nc3ccccc32)C(=O)c2ccccc21</smiles>

3k<smiles>O=C1C=C([C@]2(c3cc(F)ccc3[AsH3])C(=O)Nc3ccccc3C2=O)c2ccccc21</smiles>

$71 \%$ yield, $79 \%$ ee, $8 \mathrm{~d}$<smiles>O=C1C=C([C@]2(c3ccc(Br)cc3)C(=O)Nc3ccccc32)C(=O)c2ccccc21</smiles>

3h

$55 \%$ yield, $83 \%$ ee, $6 \mathrm{~d}$

$68 \%$ yield, $77 \%$ ee, $6 \mathrm{~d}$

$53 \%$ yield, $65 \%$ ee, 6 d

$45 \%$ yield, $54 \%$ ee, 8 d<smiles>CC1(C2=CC(=O)c3ccccc3C2=O)C(=O)Nc2ccc(Br)cc21</smiles>

$58 \%$ yield, $19 \%$ ee, $8 \mathrm{~d}$

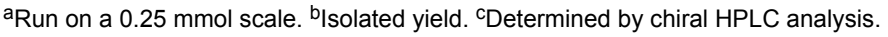

formation to the corresponding known compound [47]; all other products were tentatively assigned in analogy (for details, see Supporting Information File 1).

Other quinones such as 2,6-dichloro-1,4-benzoquinone and 1,4benzoquinone were also examined, however, none of them could react with 3-phenyloxindole 1a to give the desired product.

While the oxidation product 3 was obtained as the only product from the Michael addition, it could be hydrogenated to the corresponding hydroquinone product 4 . The free hydroxy groups were protected to prevent re-oxidation. For example, product 3i was reduced and converted to the desired 3,3-diaryloxindole 13 in $57 \%$ yield without the loss of ee. We further checked if this protocol could be operated as a "one-pot" sequential reaction. After the reaction of $\mathbf{1} \mathbf{i}$ and $\mathbf{2}$ was run at $0{ }^{\circ} \mathrm{C}$ for five days a small amount of oxindole $1 \mathbf{i}$ still remained. Then, the reaction was warmed to room temperature, followed by the addition of $\mathrm{Pd} / \mathrm{C}$ and ammonium formate. When TLC analysis revealed that the hydrogenation of product $3 \mathbf{i}$ was completed, acetyl chloride and triethylamine were added. The 
desired product 13 was obtained in 50\% yield with $75 \%$ ee (Scheme 1). The diminished enantioselectivity was due to the fact that the remaining oxindole $\mathbf{1 i}$ continued to react with $\mathbf{2}$ at room temperature during the following steps. Even if there is much potential for further improvement in the ee, this sequential reaction represented the first example of catalytic asymmetric synthesis of 3,3-diaryl oxindoles.

\section{Conclusion}

In summary, we have developed the first example of organocatalytic Michael addition of unprotected 3-prochiral oxindoles to 1,4-naphthoquinone [48] with good to high yields and enantioselectivities. This method could be used for the synthesis of enantioenriched 3,3-diaryloxindoles and the catalytic synthesis of which was unprecedented. The development of new chiral catalysts to improve both the reactivity and enantioselectivity of this reaction is now in progress in our lab.

\section{Supporting Information}

\section{Supporting Information File 1}

General experimental procedures and compound characterization.

[http://www.beilstein-journals.org/bjoc/content/ supplementary/1860-5397-8-157-S1.pdf]

\section{Acknowledgements}

The financial support from the NSFC (21172075), the 973 program (2011CB808600), Shanghai Pujiang Program
(10PJ1403100), Specialized Research Fund for the Doctoral Program of Higher Education (20090076120007), Innovation Program of SMEC (12ZZ046), and the Fundamental Research Funds for the Central Universities (East China Normal University 11043) are highly appreciated.

\section{References}

1. Shen, K.; Liu, X.; Lin, L.; Feng, X. Chem. Sci. 2012, 3, 327. doi:10.1039/c1sc00544h

2. Zhou, F.; Liu, Y.-L.; Zhou, J. Adv. Synth. Catal. 2010, 352, 1381. doi:10.1002/adsc.201000161

3. Trost, B. M.; Brennan, M. K. Synthesis 2009, 3003. doi:10.1055/s-0029-1216975

4. Badillo, J. J.; Hanhan, N. V.; Franz, A. K. Curr. Opin. Drug Discovery Dev. 2010, 13, 758.

5. Shintani, R.; Inoue, M.; Hayashi, T. Angew. Chem., Int. Ed. 2006, 45, 3353. doi:10.1002/anie.200600392

6. Ishimaru, T.; Shibata, N.; Nagai, J.; Nakamura, S.; Toru, T.; Kanemasa, S. J. Am. Chem. Soc. 2006, 128, 16488. doi:10.1021/ja0668825

7. Itoh, J.; Han, S. B.; Krische, M. J. Angew. Chem., Int. Ed. 2009, 48, 6313. doi:10.1002/anie.200902328

8. Tomita, D.; Yamatsugu, K.; Kanai, M.; Shibasaki, M. J. Am. Chem. Soc. 2009, 131, 6946. doi:10.1021/ja901995a

9. Hanhan, N. V.; Sahin, A. H.; Chang, T. W.; Fettinger, J. C.; Franz, A. K. Angew. Chem., Int. Ed. 2010, 49, 744. doi:10.1002/anie.200904393

10. Liu, L.; Zhang, S.; Xue, F.; Lou, G.; Zhang, H.; Ma, S.; Duan, W.; Wang, W. Chem.-Eur. J. 2011, 17, 7791. doi:10.1002/chem.201101025

11. Zheng, K.; Yin, C.; Liu, X.; Lin, L.; Feng, X. Angew. Chem., Int. Ed. 2011, 50, 2573. doi:10.1002/anie.201007145

12. Jia, Y.-X.; Hillgren, J. M.; Watson, E. L.; Marsden, S. P.; Kündig, E. P. Chem. Commun. 2008, 4040. doi:10.1039/b810858g<smiles>Cc1cccc([C@]2(C3=CC(=O)c4ccccc4C3=O)C(=O)Nc3ccccc32)c1</smiles>

$83 \%$ ee<smiles>Cc1cccc(C2C(=O)Nc3ccccc32)c1</smiles>
$+$

$1 i$ (1.0 equiv)

\section{1) $\mathrm{Pd} / \mathrm{C}, \mathrm{HCO}_{2} \mathrm{NH}_{4}, \mathrm{MeOH}$}

2) $\mathrm{AcCl}, \mathrm{Et}_{3} \mathrm{~N}, \mathrm{THF}$

$57 \%$ yield, 2 steps

$12(20 \mathrm{~mol} \%)$ EtOAc, $0^{\circ} \mathrm{C}, 5 \mathrm{~d}$

2) $\mathrm{Pd} / \mathrm{C}, \mathrm{HCO}_{2} \mathrm{NH}_{4}$

3) $\mathrm{AcCl}, \mathrm{Et}_{3} \mathrm{~N}$

$50 \%$ yield, one pot!<smiles>CC(=O)Oc1cc([C@]2(c3cccc(C)c3)C(=O)N(C(C)(C)C)c3ccccc32)c(OC(C)(C)C)c2ccccc12</smiles><smiles>CC(=O)Oc1cc([C@]2(c3cccc(C)c3)C(=O)N(C(C)=O)c3ccccc32)c(OC(C)=O)c2ccccc12</smiles>

$75 \%$ ee 
13. Cheng, L.; Liu, L.; Wang, D.; Chen, Y.-J. Org. Lett. 2009, 11, 3874. doi:10.1021/ol901405r

14. Shen, K.; Liu, X.; Wang, G.; Lin, L.; Feng, X. Angew. Chem., Int. Ed. 2011, 50, 4684. doi:10.1002/anie.201100758

15. Yan, W.; Wang, D.; Feng, J.; Li, P.; Zhao, D.; Wang, R. Org. Lett. 2012 14, 2512-2515. doi:10.1021/ol3007953

16. Trost, B. M.; Czabaniuk, L. C. J. Am. Chem. Soc. 2010, 132, 15534. doi:10.1021/ja1079755

17. Antonchick, A. P.; Gerding-Reimers, C.; Catarinella, M.; Schürmann, M.; Preut, H.; Ziegler, S.; Rauh, D.; Waldmann, H. Nat. Chem. 2010, 2, 735. doi:10.1038/nchem.730

18. Jiang, K.; Jia, Z.-J.; Chen, S.; Wu, L.; Chen, Y.-C. Chem.-Eur. J. 2010, 16, 2852. doi:10.1002/chem.200903009

19. Ogawa, S.; Shibata, N.; Inagaki, J.; Nakamura, S.; Toru, T.; Shiro, M. Angew. Chem., Int. Ed. 2007, 46, 8666. doi:10.1002/anie.200703317

20. He, R.; Ding, C.; Maruoka, K. Angew. Chem., Int. Ed. 2009, 48, 4559 doi:10.1002/anie.200901277

21. Mai, C.-K.; Sammons, M. F.; Sammakia, T. Org. Lett. 2010, 12, 2306. doi:10.1021/ol100666v

22. Liu, Y.-L.; Wang, B.-L.; Cao, J.-J.; Chen, L.; Zhang, Y.-X.; Wang, C.; Zhou, J. J. Am. Chem. Soc. 2010, 132, 15176. doi:10.1021/ja107858z

23. Cao, Z.-Y.; Zhang, Y.; Ji, C.-B.; Zhou, J. Org. Lett. 2011, 13, 6398. doi:10.1021/ol202705g

24. Liu, Y.-L.; Zhou, J. Chem. Commun. 2012, 48, 1919. doi:10.1039/C2CC17140F

25. Liu, Y.-L.; Zhou, F.; Cao, J.-J.; Ji, C.-B.; Ding, M.; Zhou, J. Org. Biomol. Chem. 2010, 8, 3847. doi:10.1039/c0ob00174k

26. Qian, Z.-Q.; Zhou, F.; Du, T.-P.; Wang, B.-L.; Ding, M.; Zhao, X.-L.; Zhou, J. Chem. Commun. 2009, 6753. doi:10.1039/b915257a

27.Zhou, F.; Ding, M.; Liu, Y.-L.; Wang, C.-H.; Ji, C.-B.; Zhang, J.; Zhou, J. Adv. Synth. Catal. 2011, 353, 2945. doi:10.1002/adsc.201100379

28. Ding, M.; Zhou, F.; Liu, Y.-L.; Wang, C.-H.; Zhao, X.-L.; Zhou, J. Chem. Sci. 2011, 2, 2035. doi:10.1039/c1sc00390a

29. Zhou, F.; Cao, Z.-Y.; Zhang, J.; Yang, H.-B.; Zhou, J. Chem.-Asian J. 2012, 7, 233. doi:10.1002/asia.201100773

30. Alemán, J.; Richter, B.; Jørgensen, K. A. Angew. Chem., Int. Ed. 2007, 46, 5515. doi:10.1002/anie.200701009

31. Alemán, J.; Carbrera, S.; Maerten, E.; Overgaad, J.; Jørgensen, K. A Angew. Chem., Int. Ed. 2007, 46, 5520. doi:10.1002/anie.200701207

32. Galzerano, P.; Bencivenni, G.; Pesciaioli, F.; Mazzanti, A.; Giannichi, B.; Sambri, L.; Bartoli, G.; Melchiorre, P. Chem.-Eur. J. 2009, 15, 7846. doi:10.1002/chem.200802466

33. Bui, T.; Syed, S.; Barbas, C. F., III. J. Am. Chem. Soc. 2009, 131, 8758. doi:10.1021/ja903520c

34. Kato, Y.; Furutachi, M.; Chen, Z.; Mitsunuma, H.; Matsunaga, S.; Shibasaki, M. J. Am. Chem. Soc. 2009, 131, 9168. doi:10.1021/ja903566u

35. Bravo, N.; Mon, I.; Companyó, X.; Alba, A.-N.; Moyano, A.; Rios, R. Tetrahedron Lett. 2009, 50, 6624. doi:10.1016/j.tetlet.2009.09.038

36. Li, X.; Zhang, B.; Xi, Z.-G.; Luo, S.; Cheng, J.-P. Adv. Synth. Catal. 2010, 352, 416. doi:10.1002/adsc.200900630

37. Liu, X.-L.; Wu, Z.-J.; Du, X.-L.; Zhang, X.-M.; Yuan, W.-C. J. Org. Chem. 2011, 76, 4008. doi:10.1021/jo2004378

38. Duan, S.-W.; An, J.; Chen, J.-R.; Xiao, W.-J. Org. Lett. 2011, 13, 2290. doi:10.1021/ol200550y

39. Zheng, W.; Zhang, Z.; Kaplan, M. J.; Antilla, J. C. J. Am. Chem. Soc. 2011, 133, 3339. doi:10.1021/ja109824x

40. Freund, M. H.; Tsogoeva, S. B. Synlett 2011, 503. doi:10.1055/s-0030-1259527
41. Liu, L.; Wu, D.; Li, X.; Wang, S.; Li, H.; Li, J.; Wang, W. Chem. Commun. 2012, 48, 1692. doi:10.1039/c2cc17067a

42. Li, Y.-M.; Li, X.; Peng, F.-Z.; Li, Z.-Q.; Wu, S.-T.; Sun, Z.-W.; Zhang, H.-B.; Shao, Z.-H. Org. Lett. 2011, 13, 6200. doi:10.1021/ol202624f

43. Li, L.; Chen, W.; Yang, W.; Pan, Y.; Liu, H.; Tan, C.-H.; Jiang, Z. Chem. Commun. 2012, 48, 5124. doi:10.1039/c2cc31587d

44. Liao, Y.-H.; Liu, X.-L.; Wu, Z.-J.; Du, X.-L.; Zhang, X.-M.; Yuan, W.-C. Chem.-Eur. J. 2012, 18, 6679. doi:10.1002/chem.201103293

45. Wang, C.; Yang, X.; Enders, D. Chem.-Eur. J. 2012, 18, 4832. doi:10.1002/chem.201200079

46. Bergonzini, G.; Melchiorre, P. Angew. Chem., Int. Ed. 2012, 51, 971. doi:10.1002/anie.201107443

47.Siau, W.-Y.; Li, W.; Xue, F.; Ren, Q.; Wu, M.; Sun, S.; Guo, H.; Jiang, X.; Wang, J. Chem.-Eur. J. 2012, 18, 9491. doi:10.1002/chem.201200206

During publication of our manuscript, Wang and coworkers reported the Michael addition of $\mathrm{N}$-protected 3-substituted oxindoles to 1,4-naphthoquinone.

48. The unprotected 3-substituted oxindoles are less reactive but easier to access than $\mathrm{N}$-Boc protected 3-substituted oxindoles (for discuss, see [28]). While we focused on the use of unprotected 3-prochiral oxindoles for reaction development [26-28], we tried the reaction of $N$-Boc 3-phenyloxindole and 1,4-naphthoquinone, as suggested by the referee. At the standard reaction condition, the corresponding product was obtained in $47 \%$ yield with $67 \%$ ee.

\section{License and Terms}

This is an Open Access article under the terms of the Creative Commons Attribution License (http://creativecommons.org/licenses/by/2.0), which permits unrestricted use, distribution, and reproduction in any medium, provided the original work is properly cited.

The license is subject to the Beilstein Journal of Organic Chemistry terms and conditions:

(http://www.beilstein-journals.org/bjoc)

The definitive version of this article is the electronic one which can be found at: $\underline{\text { doi: } 10.3762 / \text { bjoc. } 8.157}$ 